\title{
EFFECT OF ANISE OIL SUPPLEMENTATION ON THE PERFORMANCE OF NORFA CHICKS AND SOME BLOOD CONSTITUENTS
}

\author{
Eman A. Hussein \\ Poultry Production Department, Faculty of Agriculture, Menoufia University, Shebin El-Kom, Egypt.
}

(Received 1/5/2016, Accepted 16/6/2016)

\section{SUMMARY}

$\mathrm{T}$

he objective of this research was to determine the effect of dietary Anise oil (AO) supplementation on Norfa chick's performance and some blood parameters during the period of 4 to 16 wks of age. A total of one hundred and twenty, unsexed Norfa chicks, four weeks old, were randomly divided into 4 treatments of 30 chicks and divided into 3 replicates of 10 chicks each in a completely randomized design. Treatment groups were as follows: $T_{1}$, control basal diet without supplementation, $T_{2}, T_{3}$ and $T_{4}$ represent the supplementation of $\mathrm{AO}$ at the levels of 100,300 and $500 \mathrm{mg} / \mathrm{kg}$ diet, respectively. The experiment lasted for 16 weeks. Performance parameters, some blood parameters and economical efficiency were determined. Results showed that, the diet with $500 \mathrm{mg}$ Anise oil / Kg diet had significantly $(\mathrm{P} \leq 0.05)$ heaviest body weight, body weight gain, highest feed intake and best feed conversion ratio. Total protein and globulin significantly increased in $\mathrm{T}_{4}$ (500 $\mathrm{mg} \mathrm{AO} / \mathrm{kg}$ diet); moreover, lower total lipids and total cholesterol were also recorded for the same group.

It could be concluded from this study that supplementing Norfa chick diets with Anise oil have a beneficial effect on chick's performance and could be used as a growth promoter.

Keywords: Anise oil, performance, blood constituents, Norfa chicks.

\section{INTRODUCTION}

Poultry industry has moved to minimize the use of antibiotics as growth promoters in animal diets and growing pressure was done on livestock producers in many parts of the world to produce antibiotic free birds (Demir et al., 2005). The replacement of antibiotic growth promoters with other safe and natural alternatives is a important objective for the poultry industry. Researchers are now focusing on alternatives to replace the antibiotics; for this, spices, plant extracts and herbs received increasing attentions.

Plants and their extracts have been used traditionally in the therapy of some diseases for a long time in the world, and they have a significant role in maintaining human health. Recently plants and some extracts especially essential oils were used in researches of broiler nutrition to test their effects on broiler performance. The effect of essential oils as pharmacists is widely known in human and animal use.

Essential oils (EOs) are mixture of fragrant and volatile compounds, which are usually originated from plant, and are named with the aromatic characteristics considering the origin of plant (Oyen and Dung, 1999). Certain essential oils are found to have antibacterial ability, and also exhibit antioxidant, anti-inflammatory, anti-carcinogenic, digestion stimulating, and hypo-lipidemic activities (Viuda-Martos et al., 2010). Thus, some EOs can be used as growth promoters in animal production (Kirsti et al., 2010).

Supplementing the dietary EO would stimulate the growth performance of broilers (Bampidis et al, 2005). Broiler diets supplemented with a mixture of laurel, oregano, sage, citrus and anise EO, or a mixture of some EO significantly improved feed conversion (Cabuk et al., 2006a). Also, in a broiler trial that tested mixtures of oregano, cinnamon, cayenne pepper, thyme, and combination of organic acids and plant extracts in comparison to nutritive antibiotic avilamycin in broiler chickens showed that birds supplemented with plant extracts had higher body weight gain and increased feed consumption as compared to other groups (Rezaei-Moghadam et al., 2012). Madpouly et al. (2011) reported that supplementation of turmeric increased serum antioxidant levels and immune status of the birds. 


\section{Hussein}

Plant extracts and spices as single compound or as mixed preparations can play a role in supporting both performance and health status of animals (Alcicek et al., 2004 and Cabuk et al., 2006a).The inclusion of EO mixture (EOM consisted of six different essential oils derived from selected herbs: Oregano oil (Origanum sp.), laurel leaf oil (Laurus nobilis L.), sage leaf oil (Salvia triloba L.), myrtle leaf oil (Myrtus communis), fennel seeds oil (Foeniculum vulgare), and citrus peel oil (Citrus sp.) at a level of $24 \mathrm{mg} / \mathrm{kg}$ diet significantly improved egg production, feed efficiency and reduced the percentage of cracked/broken eggs (Cabuk et al., 2006b). Essential oil mixture and organic acid supplementation in commercial layer diets under heat stress is beneficial to egg weight and immune function (Ozek et al., 2011).

Anise (Pimpinella anisum L.), a member of the Apiaceae family, is an annual aromatic plant. The part of the plant used, is the fruit, in particular the seed and its essential oil. Anise seed is listed by the Council of Europe as natural source of feed flavoring and in the USA. It is considered as GRAS, i.e. Generally Recognized As Safe (Al-Beitawi et al., 2009). Anise has been examined for its anti-parasitic and digestion stimulating properties (Cabuk et al., 2003), as well as its antibacterial (Tabanca et al., 2003), antifungal (Soliman and Badea, 2002), antipyretic (Afifi et al., 1994), antioxidant (Gulcin et al., 2003), antimicrobial (Al-Kassie, 2008), anti-helmintic (Bhatti et al., 1996) and hypo-cholesterolemic (Craig, 1999) activities. Additionally, anise is reported to possess anticonvulsant (Pourgholam et al., 1999), antiepileptic (Janahmadi et al., 2008) and muscle relaxant (Albuquerque et al., 1995) properties. Some studies have been conducted to evaluate the use of anise seed or oil in poultry nutrition especially as growth promoters (Soltan et al., 2008; Al-Beitawi et al., 2009 and Ashan, 2011). Eltazi (2014) showed that, the diet with 400ppm anise oil had significantly heaviest body weight gain, highest feed intake, best feed conversion ratio, highest dressing percentage with highest percentages of commercial cuts (breast drumstick and thigh).

Many studies have shown positive effects of dietary essential oil on body weight. Supplementing the dietary essential oils (Cross et al., 2007) stimulated the growth performance of broilers. Ocak et al. (2008) supplemented broiler diets with a mixture of herbal essential oils and found a significant reduction in feed intake. Essential oil mixture of $200 \mathrm{ppm}$ of oregano, anise oil, clove, rosemary and turmeric plant have shown improvement in the growth performance of broilers (Al-Sultan, 2003) and (Zhang et al., 2005).

This study was carried out to gain additional information about the effect of using dietary anise oil as a natural feed additive on productive performance, some blood parameters and economic efficiency of Norfa chicks from $4-16$ weeks of age.

\section{MATERIALS AND METHODS}

The present study was conducted in the Poultry Research Farm and the Poultry Nutrition Laboratory, Faculty of Agriculture, Minufia University, Shebin El-kom. Experiment was carried out during June to August, 2015. A total of one hundred and twenty, unsexed Norfa chicks, four weeks old, were randomly divided into 4 treatments of 30 chicks and divided into 3 replicates of 10 chicks each in a completely randomized design. Feed and water were provided ad libitum. All proper husbandry practices were followed. Chicks were kept under similar conditions of managements throughout the experimental periods. Anise oil (Pimpinella anisum) was obtained from the local herbal market and then added to the experimental diets. Treatment groups were as follows: $\mathrm{T}_{1}$, Control (basal diet without supplementation), $\mathrm{T}_{2}, \mathrm{~T}_{3}$ and $\mathrm{T}_{4}$ (the basal diet supplemented with anise oil at the levels of 100,300 and $500 \mathrm{mg} / \mathrm{kg} \mathrm{diet}$, respectively).

All diets were formulated (Tables 1 and 2) to meet the nutrient requirements of Norfa chicks according to Zanaty and Ibrahim (2005). Chicks were weighed and feed intake was recorded weekly. Body weight, body weight gain and feed conversion ratio (FCR) were obtained. Economic efficiency was calculated.

At the end of the experiment (16 weeks of age), blood samples were collected from wing vein of three chicks from each replicate within each treatment in heparinized tubes and plasma was separated by centrifugation at $3500 \mathrm{rpm}$ for $15 \mathrm{~min}$ and frozen at $-20^{\circ} \mathrm{c}$ for the determination of total protein, albumin, total lipids, total cholesterol, glucose, creatinine and transaminases (ALT and AST) which were calorimetrically determined using commercial kits. The globulin values were obtained by subtracting the values of albumin from the corresponding values of total protein (Coles, 1974); also albumin / globulin ratio (A/G ratio) was calculated. 
The proximate analysis of feed (Tables 1 and 2) was determined according to the methods of (AOAC, 2011). The economic efficiency was calculated from the input - output analysis (Heady and Jensen, 1954) assuming that other head costs were constant, as follows: [(price of kg weight gain-feed cost $/ \mathrm{kg}$ gain)/ feed cost $/ \mathrm{kg}$ gain $\times 100$ ] under local conditions. Data were statistically analyzed by the completely randomized design using the statistical software of SPSS 11.0 (2011) program and the differences among means were determined using Duncan's multiple range test (Duncan 1955). Percentages were transformed to the corresponding arcsine values before performing statistical analysis.

The following statistical model was applied:

$\mathrm{Y}_{\mathrm{ij}}=\mu+\mathrm{T}_{\mathrm{i}}+\mathrm{e}_{\mathrm{ij}}$

Where: $\mathrm{Y}_{\mathrm{ij}}=$ an observation, $\quad \mu=$ Overall mean. $\mathrm{T}_{\mathrm{i}}=$ effect of treatment $(\mathrm{i}=$ control, $1,2,3)$ and $\mathrm{e}_{\mathrm{ij}}=$ experimental random error.

Table (1). Composition and chemical analysis of the experimental Norfa chick diets fed during periods $(4-8)$ weeks of age

\begin{tabular}{|c|c|c|c|c|c|}
\hline \multirow[b]{2}{*}{ Ingredients } & \multicolumn{5}{|c|}{ Diets $^{1}$} \\
\hline & $\begin{array}{c}\mathrm{T}_{1} \\
\text { Control }\end{array}$ & $\mathrm{T}_{2}$ & $\mathrm{~T}_{3}$ & $\mathrm{~T}_{4}$ & $\begin{array}{c}\text { Price / } 1000 \mathrm{~kg} \\
\text { (LE) }\end{array}$ \\
\hline Ground yellow corn $(8.9 \%)$ & 66.66 & 66.65 & 66.63 & 66.61 & 2800 \\
\hline Soybean meal $(44 \%)$ & 19.12 & 19.12 & 19.12 & 19.12 & 3870 \\
\hline Wheat bran & $10 . .95$ & $10 . .95$ & 10.95 & 10.95 & 1500 \\
\hline Anise oil (AO) & - & 0.01 & 0.03 & 0.05 & 4000 \\
\hline Limestone, ground & 1.65 & 1.65 & 1.65 & 1.65 & 500 \\
\hline Di-calcium phosphate & 0.95 & 0.95 & 0.95 & 0.95 & 1500 \\
\hline Vitamin and mineral mixture ${ }^{2}$ & 0.25 & 0.25 & 0.25 & 0.25 & 8300 \\
\hline L- Lysine & 0.10 & 0.10 & 0.10 & 0.10 & 3000 \\
\hline DL-methionine $^{3}$ & 0.07 & 0.07 & 0.07 & 0.07 & 3400 \\
\hline Sodium chloride (salt) & 0.25 & 0.25 & 0.25 & 0.25 & 500 \\
\hline Total & 100 & 100 & 100 & 100 & - \\
\hline \multicolumn{6}{|l|}{ Calculated values ${ }^{4}:$} \\
\hline Crude protein,$\%$ & 16.04 & 16.04 & 16.04 & 16.04 & - \\
\hline $\mathrm{ME}, \mathrm{Kcal} / \mathrm{kg}$ diet & 2805 & 2806 & 2807 & 2807 & - \\
\hline $\mathrm{C} / \mathrm{P}$ ratio & 175 & 175 & 175 & 175 & - \\
\hline Lysine, \% & 0.84 & 0.84 & 0.84 & 0.84 & - \\
\hline Methionine, $\%$ & 0.33 & 0.33 & 0.33 & 0.33 & - \\
\hline Calcium, $\%$ & 0.91 & 0.91 & 0.91 & 0.91 & - \\
\hline Av. phosphorus , $\%$ & 0.40 & 0.40 & 0.40 & 0.40 & - \\
\hline \multicolumn{6}{|l|}{ Determined Values: } \\
\hline Dry matter, $\%$ & 90.03 & 89.96 & 89.98 & 90.00 & - \\
\hline Crude protein, $\%$ & $15 . .98$ & $15 . .95$ & $15 . .97$ & $15 . .98$ & - \\
\hline Ether extract, \% & 2.95 & 2.98 & 3.04 & 3.08 & - \\
\hline Crude fiber, $\%$ & 3.74 & 3.76 & 3.78 & 3.78 & - \\
\hline Price / $1000 \mathrm{Kg}(\mathrm{LE})^{5}$ & 2821 & 2881 & 2941 & 3021 & \\
\hline
\end{tabular}

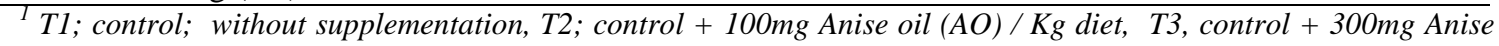
oil (AO) / Kg diet; T4, control + 500mg Anise oil (AO) / Kg

${ }^{2}$ Vitamin and Mineral mixture at 0.30\% of the diet supplies the following per kilogram of the diet: vit.A, 1200 IU; Vit.D3, 2500 IU; Vit. E, $10 \mathrm{mg}$; Vit.K3, 3mg; Vit.B1, Img; Vit.B2, 4mg; pant othenic acid, $10 \mathrm{mg}$; Nicotinic acid, $20 \mathrm{mg}$; Folic-acid, $1 \mathrm{mg}$; Biotin, $0.05 \mathrm{mg}$; Niacin, $40 \mathrm{mg}$; Vit.B6, $3 \mathrm{mg}$, Vit. B12, $20 \mathrm{mcg}$; Choline Chloride, 400 $\mathrm{mg}$; Mn, $62 \mathrm{mg}$; $\mathrm{Fe}, 44 \mathrm{mg}$; Zn, $56 \mathrm{mg}$; $1,1 \mathrm{mg} ; \mathrm{Cu}, 5 \mathrm{mg}$ and Se, 0.01mg.

${ }^{3}$ Dl-Methionine: $98 \%$ feed grade (contains $98 \%$ methionine).

${ }^{4}$ Calculated according to NRC (1994).

${ }^{5}$ Based on prices of Egyptian market, $6 / 2015$. 


\section{Hussein}

Table (2). Composition and chemical analysis of the experimental Norfa chick diets fed during periods $(8$ - 16) weeks of age

\begin{tabular}{|c|c|c|c|c|c|}
\hline \multirow[b]{2}{*}{ Ingredients } & \multicolumn{5}{|c|}{ Diets $^{1}$} \\
\hline & $\begin{array}{c}\mathrm{T}_{1} \\
\text { Control }\end{array}$ & $\mathrm{T}_{2}$ & $\mathrm{~T}_{3}$ & $\mathrm{~T}_{4}$ & $\begin{array}{l}\text { Price / } 1000 \mathrm{~kg} \\
\text { (LE) }\end{array}$ \\
\hline Ground yellow corn $(8.9 \%)$ & 60.38 & 60.37 & 60.35 & $60 . .33$ & 2800 \\
\hline Soybean meal $(44 \%)$ & 10.28 & 10.28 & 10.28 & 10.28 & 3870 \\
\hline Wheat bran & 26.60 & 26.60 & 26.60 & 26.60 & 1500 \\
\hline Anise oil (AO) & - & 0.01 & 0.03 & 0.05 & 4000 \\
\hline Limestone, ground & 1.86 & 1.86 & 1.86 & 1.86 & 500 \\
\hline Di-calcium phosphate & 0.14 & 0.14 & 0.14 & 0.14 & 1500 \\
\hline Vitamin and mineral mixture $^{2}$ & 0.09 & 0.09 & 0.09 & 0.09 & 8300 \\
\hline L- Lysine & 0.05 & 0.05 & 0.05 & 0.05 & 3000 \\
\hline DL-methionine $^{3}$ & 0.25 & 0.25 & 0.25 & 0.25 & 3400 \\
\hline Sodium chloride (salt) & 0.35 & 0.35 & 0.35 & 0.35 & 500 \\
\hline Total & 100 & 100 & 100 & 100 & - \\
\hline \multicolumn{6}{|l|}{ Calculated values ${ }^{4}$} \\
\hline Crude protein,$\%$ & 16.04 & 16.04 & 16.04 & 16.04 & - \\
\hline $\mathrm{ME}, \mathrm{Kcal} / \mathrm{kg}$ diet & 2805 & 2806 & 2807 & 2807 & - \\
\hline $\mathrm{C} / \mathrm{P}$ ratio & 175 & 175 & 175 & 175 & - \\
\hline Lysine, \% & 0.84 & 0.84 & 0.84 & 0.84 & - \\
\hline Methionine, $\%$ & 0.33 & 0.33 & 0.33 & 0.33 & - \\
\hline Calcium, $\%$ & 0.91 & 0.91 & 0.91 & 0.91 & - \\
\hline Av. phosphorus , $\%$ & 0.40 & 0.40 & 0.40 & 0.40 & - \\
\hline \multicolumn{6}{|l|}{ Determined Values } \\
\hline Dry matter, $\%$ & $89 . .93$ & $89 . .94$ & 89.96 & 89.98 & - \\
\hline Crude protein, $\%$ & 13.89 & 13.91 & 13.95 & 13.97 & - \\
\hline Ether extract, \% & 3.11 & 3.16 & 3.19 & 3.22 & - \\
\hline Crude fiber, $\%$ & 3.98 & 3.98 & 4.03 & 4.05 & - \\
\hline Price / $1000 \mathrm{~kg}(\mathrm{LE})^{5}$ & 2517 & 2557 & 2637 & 2717 & - \\
\hline \multicolumn{6}{|c|}{$\begin{array}{l}\text { T1; control; without supplementation, T2; control }+100 \mathrm{mg} \text { Anise oil }(\mathrm{AO}) / \mathrm{Kg} \text { diet, T3, control }+300 \mathrm{mg} \text { Anise } \\
\text { oil }(\mathrm{AO}) / \mathrm{Kg} \text { diet; } \mathrm{T4}, 5 \text { control }+ \text { OOmg Anise oil }(\mathrm{AO}) / \mathrm{Kg} .\end{array}$} \\
\hline \multicolumn{6}{|c|}{ 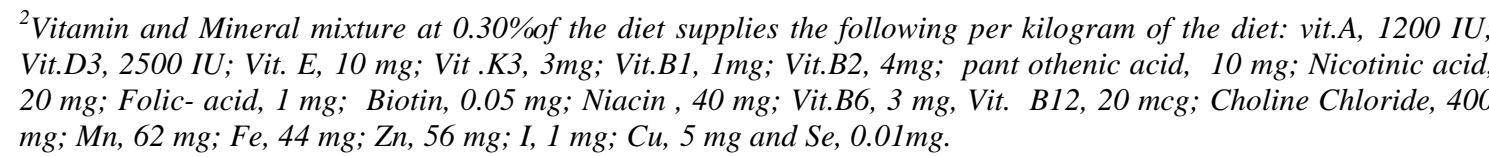 } \\
\hline \multicolumn{6}{|c|}{${ }^{3}$ Dl-Methionine: $98 \%$ feed grade (contains $98 \%$ methionine). } \\
\hline \multicolumn{6}{|c|}{${ }^{4}$ Calculated according to NRC (1994). } \\
\hline${ }^{5}$ Based on prices of Egyptian $m$ & & & & & \\
\hline
\end{tabular}

\section{RESULTS and DISCUSSION}

\section{Growth Performance}

The effect of feeding different levels of Anise oil (AO) on Norfa chick performance is shown in Tables (3 and 4). Final body weight, body weight gain, was significantly $(\mathrm{P} \leq 0.05)$ affected by the addition of anise oil to chick diets. At 16 weeks of age, the average body weight (BW) was significantly increased $(\mathrm{P} \leq 0.05)$ with the $500 \mathrm{mg} \mathrm{AO} / \mathrm{kg}$ diet being; 1024.42g compared to other dietary treatments $\mathrm{T}_{2}, \mathrm{~T}_{3}$ and $\mathrm{T}_{1}$, control $(949.46,993.12$ and $914.65 \mathrm{~g})$ in a respective order. Chicks consuming the control diet had a body weight gain (BWG) of $156.03 \mathrm{~g}$ in compression with $162.60,168.00$ and $174.84 \mathrm{~g}$ for $\mathrm{T}_{2}$, $\mathrm{T}_{3}$ and $\mathrm{T}_{4}$, respectively.

This may be attributed to Anise oil which contains some active items such as anathol (\%85), eugenol, methylchavicol and anisaldehyde. Anathol and eugenol increase body weight gain and improve feed conversion by destroying the pathogen microorganism in digestive system, increasing production of digestive enzymes, improving utilization of digestive products and enhancing liver functions (Langhout, 2000; Williams and Losa, 2001; Cabuk, et al., 2003; Hernandez et al., 2004 and Osman et al., 2005). In this study, the improved body weight in the $500 \mathrm{mg} \mathrm{AO} / \mathrm{kg}$ diet group may be due to these positive effects 
of anise oil on digestive system. In agreement with these results, Simsek et al. (2007) and Eltazi (2014) stated that, the improved body weight with 400ppm of anise oil diet could be been due to positive effects of anise oil on digestive system.

Table (3). Effect of different levels of Anise oil (AO) on body weight and body weight gain of Norfa chicks during the experimental periods (Mean $\pm \mathrm{SE}$ )

\begin{tabular}{|c|c|c|c|c|}
\hline \multirow[t]{2}{*}{ Periods } & \multicolumn{4}{|c|}{ Dietary treatments $^{1}$} \\
\hline & $\mathrm{T}_{1}$ Control & $\mathrm{T}_{2}$ & $\mathrm{~T}_{3}$ & $\mathrm{~T}_{4}$ \\
\hline \multicolumn{5}{|c|}{ Body weights ( $g$ ) } \\
\hline $\mathrm{IBW}^{2}(4 \mathrm{Wk})$ & $133.73 \pm 4.55$ & $134.36 \pm 5.28$ & $133.66 \pm 11.36$ & $133.83 \pm 6.75$ \\
\hline $6 \mathrm{Wk}$ & $191.43 \pm 3.59^{\mathrm{c}}$ & $197.00 \pm 3.66^{\mathrm{c}}$ & $215.23 \pm 6.12^{\mathrm{b}}$ & $218.91 \pm 2.75^{\mathrm{a}}$ \\
\hline $8 \mathrm{Wk}$ & $317.96 \pm 5.31^{\mathrm{c}}$ & $326.36 \pm 11.56^{\mathrm{ab}}$ & $349.54 \pm 9.15^{\mathrm{b}}$ & $357.91 \pm 9.46^{\mathrm{a}}$ \\
\hline $10 \mathrm{Wk}$ & $453.7 \pm 17.10^{\mathrm{c}}$ & $466.36 \pm 4.51^{\mathrm{ab}}$ & $496.76 \pm 7.11^{\mathrm{b}}$ & $510.07 \pm 13.20^{\mathrm{a}}$ \\
\hline $12 \mathrm{Wk}$ & $601.62 \pm 13.25^{\mathrm{c}}$ & $621.39 \pm 11.12^{\mathrm{b}}$ & $656.12 \pm 19.13^{\mathrm{a}}$ & $676.69 \pm 8.55^{\mathrm{a}}$ \\
\hline $14 \mathrm{Wk}$ & $758.62 \pm 11.41^{\mathrm{d}}$ & $786.86 \pm 15.21^{\mathrm{c}}$ & $825.12 \pm 17.63^{\mathrm{b}}$ & $853.58 \pm 10.34^{\mathrm{a}}$ \\
\hline $16 \mathrm{Wk}$ & $914.65 \pm 9.76^{\mathrm{d}}$ & $949.46 \pm 12.32^{c}$ & $993.12 \pm 18.89^{\mathrm{b}}$ & $1028.42 \pm 11.23^{\mathrm{a}}$ \\
\hline \multicolumn{5}{|c|}{ Body weight gain $(g)$} \\
\hline $4-6 \mathrm{Wk}$ & $57.7 \pm 2.14^{\mathrm{c}}$ & $62.64 \pm 1.23^{\mathrm{b}}$ & $81.57 \pm 1.53^{\mathrm{a}}$ & $85.08 \pm 3.25^{\mathrm{a}}$ \\
\hline $6-8 \mathrm{Wk}$ & $126.53 \pm 3.95^{\mathrm{c}}$ & $129.36 \pm 6.12^{\mathrm{ab}}$ & $134.31 \pm 2.84^{\mathrm{b}}$ & $139.00 \pm 1.10^{\mathrm{a}}$ \\
\hline $8-10 \mathrm{Wk}$ & $135.74 \pm 2.76^{c}$ & $140.00 \pm 3.25^{\mathrm{ab}}$ & $147.22 \pm 2.29^{b}$ & $152.16 \pm 3.33^{\mathrm{a}}$ \\
\hline $10-12 \mathrm{Wk}$ & $147.92 \pm 1.90^{\mathrm{c}}$ & $155.03 \pm 1.28^{\mathrm{ab}}$ & $159.36 \pm 4.40^{\mathrm{b}}$ & $166.62 \pm 1.11^{\mathrm{a}}$ \\
\hline $12-14 \mathrm{Wk}$ & $157.00 \pm 2.22^{c}$ & $165.47 \pm 1.22^{\mathrm{ab}}$ & $169.00 \pm 3.49^{\mathrm{b}}$ & $176.89 \pm 2.12^{\mathrm{a}}$ \\
\hline $14-16 \mathrm{Wk}$ & $156.03 \pm 2.36^{\mathrm{c}}$ & $162.60 \pm 3.00^{\mathrm{ab}}$ & $168.00 \pm .89^{\mathrm{b}}$ & $174.84 \pm 1.33^{\mathrm{a}}$ \\
\hline $4-16 \mathrm{Wk}$ & $780.92 \pm 6.10^{c}$ & $815.10 \pm 3.27^{\mathrm{ab}}$ & $859.46 \pm 2.14^{\mathrm{b}}$ & $894.84 \pm 4.95^{\mathrm{a}}$ \\
\hline
\end{tabular}

Table (4). Effect of different levels of Anise oil (AO) on feed intake and feed conversion of Norfa chicks during the experimental periods (Mean $\pm \mathrm{SE})$

\begin{tabular}{|c|c|c|c|c|}
\hline \multirow[t]{2}{*}{ Periods } & \multicolumn{4}{|c|}{ Dietary treatments $^{1}$} \\
\hline & $\mathrm{T}_{1}$ Control & $\mathrm{T}_{2}$ & $\mathrm{~T}_{3}$ & $\mathrm{~T}_{4}$ \\
\hline \multicolumn{5}{|c|}{ Feed intake, FI (g/bird) } \\
\hline $4-6 w k$ & $144.25 \pm 8.33^{\mathrm{d}}$ & $155.35 \pm 6.23^{\mathrm{c}}$ & $199.85 \pm 5.11^{\mathrm{b}}$ & $205.89 \pm 10.32^{\mathrm{a}}$ \\
\hline $6-8 w k$ & $325.18 \pm 2.36^{\mathrm{c}}$ & $328.57 \pm 11.00^{\mathrm{bc}}$ & $333.09 \pm 1.29^{\mathrm{b}}$ & $339.16 \pm 2.20^{\mathrm{a}}$ \\
\hline $8-10 \mathrm{wk}$ & $403.15 \pm 1.95^{\mathrm{b}}$ & $406.00 \pm 5.55^{\mathrm{b}}$ & $413.69 \pm 5.21^{\mathrm{a}}$ & $418.44 \pm 3.26^{\mathrm{a}}$ \\
\hline $10-12 \mathrm{wk}$ & $470.39 \pm 1.12^{\mathrm{bc}}$ & $488.34 \pm 1.52^{\mathrm{c}}$ & $498.80 \pm 4.31^{\mathrm{b}}$ & $504.86 \pm 2.22^{\mathrm{a}}$ \\
\hline $12-14 \mathrm{wk}$ & $543.22 \pm 3.30^{\mathrm{bc}}$ & $552.84 \pm 9.21^{\mathrm{c}}$ & $549.25 \pm 1.02^{\mathrm{b}}$ & $566.05 \pm 1.54^{\mathrm{a}}$ \\
\hline $14-16 \mathrm{wk}$ & $596.03 \pm 2.68^{\mathrm{d}}$ & $614.62 \pm 3.10^{c}$ & $621.60 \pm 2.21^{\mathrm{b}}$ & $636.42 \pm 1.09^{\mathrm{a}}$ \\
\hline $4-16 w k$ & $2912.83 \pm 10.11^{\mathrm{d}}$ & $2983.27 \pm 6.65^{\mathrm{c}}$ & $3059.68 \pm 8.64^{b}$ & $3131.07 \pm 4.59^{\mathrm{a}}$ \\
\hline \multicolumn{5}{|c|}{ Feed conversion, FC ( $g$ feed/g gain) } \\
\hline $4-6 \mathrm{wk}$ & $2.50 \pm 0.06^{\mathrm{c}}$ & $2.48 \pm 0.04^{\mathrm{b}}$ & $2.45 \pm 0.03^{\mathrm{b}}$ & $2.42 \pm 0.04^{\mathrm{a}}$ \\
\hline $6-8 w k$ & $2.57 \pm 0.03^{c}$ & $2.54 \pm 0.06^{\mathrm{c}}$ & $2.48 \pm 0.01^{\mathrm{b}}$ & $2.44 \pm 0.02^{\mathrm{a}}$ \\
\hline $8-10 \mathrm{wk}$ & $2.97 \pm 0.04^{\mathrm{c}}$ & $2.90 \pm 0.06^{\mathrm{c}}$ & $2.81 \pm 0.04^{b}$ & $2.75 \pm 0.04^{\mathrm{a}}$ \\
\hline $10-12 \mathrm{wk}$ & $3.18 \pm 0.01^{\mathrm{c}}$ & $3.15 \pm 0.02^{\mathrm{ab}}$ & $3.13 \pm 0.01^{\mathrm{b}}$ & $3.03 \pm 0.04^{\mathrm{a}}$ \\
\hline $12-14 \mathrm{wk}$ & $3.46 \pm 0.06^{b c}$ & $3.40 \pm 0.05^{\mathrm{c}}$ & $3.25 \pm 0.01^{\mathrm{b}}$ & $3.20 \pm 0.02^{\mathrm{a}}$ \\
\hline 14-16wk & $3.82 \pm 0.05^{\mathrm{c}}$ & $3.78 \pm 0.03^{\mathrm{ab}}$ & $3.70 \pm 0.04^{\mathrm{b}}$ & $3.64 \pm 0.06^{\mathrm{a}}$ \\
\hline 4-16 wk & $3.73 \pm 0.05^{\mathrm{d}}$ & $3.66 \pm 0.04^{\mathrm{c}}$ & $3.56 \pm 0.04^{\mathrm{a}}$ & $3.50 \pm 0.05^{\mathrm{a}}$ \\
\hline
\end{tabular}

In addition, Hernandez et al. (2004) reported that supplementation of essential oil extract from oregano, cinnamon and pepper improved apparent whole tract and ileac digestibility of the nutrients in broilers. The result was agreement with the findings of Jang et al. (2004) who showed that supplementation of a blend of commercial essential oils combined with lactic acid increased trypsin and 


\section{Hussein}

pancreatic amylase activity in broiler. The results coincided with the findings of Ertas et al. (2005) who reported that the addition of essential oils mixture (oregano, clove and anise) in the diet improved body weight of broilers. In addition, positive effects of dietary essential oils on body weight were observed by Alcicek et al. (2003) and Denli et al. (2004). Moreover, Jamroz et al. (2003) found that the inclusion of 150 or $300 \mathrm{mg} / \mathrm{kg}$ of a plant extract containing capsaicin, carvacrol and cinnamicaldehyde in the diet improved body weight by 5.4 and $8.1 \%$, respectively. In contrast, Botsoglou et al. (2004) reported that the supplementation of essential oils (oregano and rosemary essential oil) to a diet had no beneficial effect on body weight. Similar result was observed by Jamroz et al. (2005) who noted that a plant extract included in a broiler diet did not improve body weight. The diets with 150 and $250 \mathrm{ppm}$ anise oil significantly $(\mathrm{P} \leq 0.05)$ showed lower body weight and body weight gain compared to the positive control diet.

The results showed that chicks fed supplemented diets significantly consumed more amount of feed compared to the chicks fed control diet (Table 4). The diet with $500 \mathrm{mg} / \mathrm{kg}$ diet significantly $(\mathrm{P} \leq 0.05)$ recorded the highest feed intake $(3131.07 \mathrm{~kg})$ in compression with other experimental diets control, $\mathrm{T}_{2}$ and $\mathrm{T}_{3},(2912.83,2983$ and $3059.68 \mathrm{Kg})$, respectively. The diet with $500 \mathrm{mg} / \mathrm{kg}$ anise oil significantly $(\mathrm{P} \leq 0.05)$ recorded better feed conversion ratio (3.5) compared to other experimental diets and control (3.66, 3.56 and 3.73), respectively. The obtained results confirmed the previous findings of several researches (Simsek et al., 2007 and Eltazi, 2014) who reported that the diet with 400 ppm anise oil significantly (P $\leq$ $0.05)$ had the highest feed intake compared to other experimental diets. This increase feed intake may be attributed to the appetizing effect of active ingredient, such as anethol in anise (Cabuk et al., 2003). Similar result was obtained by Ertas et al. (2005) who reported that the addition of essential oil mixture (oregano, clove and Anise) in the diet increased the feed intake of broilers. In contrast, Lee et al. (2003); Botsoglou et al. (2004) and Hernandez et al. (2004) reported that addition of plant extracts or essential oils (essential oil extract (EOE) from oregano, cinnamon, and pepper; and Labiatae extract (LE) from sage, thyme, and rosemary) to the diet had no effect on feed intake.

The improvement in feed conversion ratio in the diet at a level of $400 \mathrm{ppm}$ could be related to the digestive stimulating effect of anise (Cabuk et al., 2003), particularly the digestion of protein and fat (Jamroz and Kamel, 2002). In addition, several researchers reported that anise oil significantly improved the feed conversion ratio of broiler chickens (Ather, 2000; Williams and Losa, 2001 and Giannenas et al., 2003).

\section{Blood constituents}

Results of blood constituents as affected by different levels of anise oil are summarized in Table 5. It is clear that chicks fed $500 \mathrm{mg} \mathrm{AO} / \mathrm{kg}$ diet $\left(\mathrm{T}_{4}\right)$ had the highest values of total protein, albumin and globulin concentrations compared to other dietary treatments. Nevertheless, feeding Norfa chicks 300 or $500 \mathrm{mg} \mathrm{AO} / \mathrm{kg}$ diet $\left(\mathrm{T}_{3}\right.$ and $\left.\mathrm{T}_{4}\right)$ reduced the values of total lipids, glucose and total cholesterol in comparison with those fed the control or $100 \mathrm{mg} \mathrm{AO} / \mathrm{kg}$ diet $\left(\mathrm{T}_{2}\right)$. There were no adverse effects on blood components representing liver function (as measured by ALT and AST) or kidneys functions (as measured by creatinine levels). Results reported herein are in agreement with previous findings of AlMashhadani, et al. (2011) who stated that there was a decrease in plasma cholesterol and glucose for chicks fed diets contained anise oil. Lemhadri (2004) reported that an equeous organo extract exhibited an anti-hyperglycemic activity in rats without affecting basal plasma glucose concentration. On the other hand, Ashan (2011) found that anise oil supplementation had no adverse effects on blood biochemical parameters.

\section{Economic efficiency}

The economic efficiency of the experimental treatments (Table 6) indicates that the highest economic and relative economic efficiency values were obtained with the diet supplemented with graded levels of $\mathrm{AO}$ as a natural additive. It may be due to better feed conversion of birds received the experimental diets. El-tazi (2014) indicated that the economic evaluation of the diet supplemented with 400ppm level of anise oil showed the highest profitability ratio (1.8). This may be related to the higher return of the weight gains recorded in this group of chicks compared to other treatments.

\section{CONCLUSION}

It could be concluded from this study that supplementing Norfa chick diets with the level of 500ppm of the Anise oil (AO) has a beneficial effect on chick's performance and could be recommended to be used as growth promoters. 
Table (5). Effect of supplemental Anise oil (AO) on some blood plasma constituents of Norfa chicks at 16 weeks of age

\begin{tabular}{|c|c|c|c|c|}
\hline \multirow[t]{2}{*}{ Item } & \multicolumn{4}{|c|}{ Dietary treatments $^{1}$} \\
\hline & $\begin{array}{ll}\mathrm{T}_{1} & \text { Control } \\
\end{array}$ & $\mathrm{T}_{2}$ & $\mathrm{~T}_{3}$ & $\mathrm{~T}_{4}$ \\
\hline Total protein $(\mathrm{g} / \mathrm{dI})$ & $4.12 \pm 0.04^{\mathrm{c}}$ & $4.19 \pm 0.03^{b}$ & $4.23 \pm 0.04^{\mathrm{a}}$ & $4.31 \pm 0.05^{\mathrm{a}}$ \\
\hline Albumin $(\mathrm{A})(\mathrm{g} / \mathrm{dl})$ & $2.28 \pm 0.01^{\mathrm{ab}}$ & $2.32 \pm 0.02^{\mathrm{b}}$ & $2.35 \pm 0.02^{\mathrm{b}}$ & $2.41 \pm 0.04^{\mathrm{a}}$ \\
\hline Globulin $(\mathrm{g})(\mathrm{g} / \mathrm{dl})$ & $1.74 \pm 0.04^{\mathrm{c}}$ & $1.83 \pm 0.02^{\mathrm{b}}$ & $1.90 \pm 0.04^{\mathrm{a}}$ & $1.98 \pm 0.04^{\mathrm{a}}$ \\
\hline A / G ratio & $1.31 \pm 0.02^{\mathrm{a}}$ & $1.26 \pm 0.02^{\mathrm{a}}$ & $1.24 \pm 0.01^{\mathrm{b}}$ & $1.22 \pm 0.02^{\mathrm{b}}$ \\
\hline Total lipids, mg/dl & $510.13 \pm 0.02^{\mathrm{a}}$ & $482.61 \pm 0.01^{\mathrm{b}}$ & $452.00 \pm 0.03^{\mathrm{c}}$ & $428.56 \pm 0.0^{\mathrm{d}}$ \\
\hline Total cholesterol (mg/dl) & $146.13 \pm 0.03^{\mathrm{a}}$ & $142.87 \pm 0.04^{\mathrm{b}}$ & $135.97 \pm 0.03^{b}$ & $131.42 \pm 0.01^{\mathrm{c}}$ \\
\hline Glucose (mg/dI) & $189.36 \pm 0.03^{\mathrm{a}}$ & $181.54 \pm 0.02^{\mathrm{b}}$ & $167.60 \pm 0.03^{\mathrm{c}}$ & $143.20 \pm 0.0^{\mathrm{d}}$ \\
\hline Creatinine $(\mathrm{mg} / \mathrm{dl})$ & $1.42 \pm 0.02^{\mathrm{a}}$ & $1.35 \pm 0.01^{\mathrm{b}}$ & $1.37 \pm 0.01^{\mathrm{b}}$ & $1.40 \pm 0.01^{\mathrm{a}}$ \\
\hline $\operatorname{ALT}(\mathrm{U} / \mathrm{L})$ & $145.00 \pm 0.02^{\mathrm{b}}$ & $146.12 \pm 0.02^{\mathrm{a}}$ & $145.06 \pm 0.02^{\mathrm{a}}$ & $147.20 \pm 0.01^{\mathrm{a}}$ \\
\hline AST (U/L) & $38.96 \pm 0.02^{\mathrm{c}}$ & $39.10 \pm 0.02^{\mathrm{b}}$ & $39.19 \pm 0.01^{\mathrm{b}}$ & $39.31 \pm 0.03^{\mathrm{a}}$ \\
\hline
\end{tabular}

Table (6). The economic efficiency of the experimental diets of Norfa chicks fed during from $(8-16$ weeks of age)

\begin{tabular}{|c|c|c|c|c|}
\hline \multirow[t]{2}{*}{ Item } & \multicolumn{4}{|c|}{ Dietary treatments $^{1}$} \\
\hline & $\mathrm{T}_{1}$ Control & $\mathrm{T}_{2}$ & $\mathrm{~T}_{3}$ & $\mathrm{~T}_{4}$ \\
\hline Body weight gain(g) & 597 & 623 & 644 & 671 \\
\hline Total revenue (L.E) ${ }^{1}$ & 8.36 & 8.72 & 9.02 & 9.39 \\
\hline Feed intake ( Kg) & 2.18 & 2.22 & 2.25 & 2.23 \\
\hline Price of $\mathrm{Kg}$ feed ( L.E) & 2.52 & 2.56 & 2.64 & 2.72 \\
\hline Feed cost ( L.E) & 5.49 & 5.68 & 5.84 & 6.06 \\
\hline Net revenue $(\mathrm{L} . \mathrm{E})^{2}$ & 2.87 & 3.04 & 3.18 & 3.33 \\
\hline Economic efficiency, $(\%)$ & 52.28 & 53.52 & 54.45 & 54.95 \\
\hline Economic efficiency relative $(\%)$ & 100 & 102.37 & 104.15 & 105.11 \\
\hline \multicolumn{5}{|c|}{$\begin{array}{l}{ }^{1} T_{1}, \text { control; } \text { without supplementation, } T_{2} \text {; control }+100 \mathrm{mg} \text { Anise oil }(\mathrm{AO}) / \mathrm{Kg} \text { diet, } T_{3,} \text { control }+300 \mathrm{mg} \text { Anise oil } \\
(\mathrm{AO}) / \mathrm{Kg} \text { diet } ; \mathrm{T}_{4} \text {, control }+500 \mathrm{mg} \text { Anise oil }(\mathrm{AO}) / \mathrm{Kg} .\end{array}$} \\
\hline \multicolumn{5}{|c|}{ - Assuming the price of one - Kg live body weight was $15 E$ (according to Egyptian market, 6 /2015). } \\
\hline \multicolumn{5}{|c|}{${ }^{1}$ Total revenue $=$ Body weight gain $(\mathrm{Kg}) x$ Price of one $-\mathrm{Kg}$ live body weight.} \\
\hline \multicolumn{5}{|c|}{${ }^{2}$ Net revenue $=$ Total revenue - Feed cost.} \\
\hline${ }^{3}$ Economical efficiency $=($ Net reven $t$ & st) & & & \\
\hline
\end{tabular}

\section{REFERENCES}

Al-Beitawi, N.A., S. S. El-Ghousein and H. M. Abdullah, 2009. Antibiotic growth promoters and anise seeds in broiler diets. Jordan J. Agric. Sci., 5: 472-481.

Albuquerque, A. A., A. L. Sorenson, and J. H. Leal-Cardoso, 1995. Effects of essential oil of crotonzehntneri, anethol and estragole on skeletal muscles. J.Ethnopharmacology, 49: 41-49.

Alcicek, A., M. Bozkurt and M. Cabuk, 2003. The effect of an essential oil combination derived from selected herbs growing wild in Turkey on broiler performance. S. Afr. J. Anim. Sci., 33: 89-94.

Alcicek, A., M. Bozkurt and M. Cabuk, 2004. The effect of a mixture of herbal essential oils, an organic acid or a probiotic on broiler performance. S. Afr. J. Anim. Sci., 34: 217-222.

Afifi, N.A., A. Ramadan, E. A. El-Kashoury and H. A. El Banna, 1994. Some pharmacological activities of essential oils of certain umbelliferous fruits. Vet. Med. J. Giza 42: 85-92.

Al - Kassie, G. A. M., 2008. The Effect of Anise and Rosemary on Broiler Performance. Int. J. Poult. Sci., 7 (3): 243-245. ISSN 1682-8356. 


\section{Hussein}

Al - Mashhadani, E. H., K. A. Farah, M. F. Yansoon and Hanan E. Al- Mashhadani, 2011. Effect of Anise, Thyme essential oils and their mixture (EOM) on broiler performance and some physiological traits. Egypt, Poult. Sci. Vol. (31) (II): (481 - 489).

Al-Sultan, S.I., 2003. The effect of Curcuma longa (turmeric) on overall performance of broiler chickens. Int. J. Poult. Sci., 2: 351-353.

Ashan, S. K., 2011. Effect of Herbal oil on performance, carcass quality, blood parameters and Immune System in female broiler chicken. Annals of Biological Research, 2, (5):589-592.

Ather, M. A. M., 2000. Polyhedral additive proves effective against vertical transmission of IBD. World Poult. Elsevier, 16: 50-52.

AOAC., 2011. Official methods of analytical chemists.18th ed. Association of Official Analytical Chemists, Arlington, VA, USA.

Bampidis V. A.,V. Christodoulou, P. P. Florou, E. Christaki, P. S. Chatzopoulou, T. Tsiligianni and A. B. Spais, 2005. Effect of dietary dried oregano leaves on growth performance, carcase characteristics and serum cholesterol of female early maturing turkeys. Br. J. of Poult. Sci., 46: 595- 601.

Bhatti, M. A., M. T. J. Khan, B. Ahmed, M. Jamshaid and W. Ahmad, 1996. Antibacterial activity of anise seed (Pimpinella anisum). Fitoterapia, 67: 372- 374.

Botsoglou, N. A., E. Christaki, P. Elorou-Paneri, I. Giannenas, G. Papageorgiou and A. B. Spais, 2004. The effect of a mixture of herbal essential oils or a-tocophery $\mathrm{L}$ acetate on performance parameters and oxidation of body lipid in broilers. S. Afr. J. anim. Sci., 34:52-61.

Cabuk, M., A. Alcicek, M. Bozkurt N. and N. Imre,2003. Antimicrobial properties of the essential oils isolated from aromatic plants and using possibility as alternative feed additives. II National animal Nutrition Congress, 18-20 September, pp. 184-187.

Cabuk, M., M. Bozkurt, A. Alcicek, Y. Akbap and K. Kucukyllmaz, 2006a. Effect of a herbal essential oil mixture on growth and internal organ weight of broilers from young and old breeder flocks. S. Afr. J. anim. Sci., 36: 135-141.

Cabuk, M., M. Bozkurt, A. Alcicek, A. U. Catli and K. H. C. Baser, 2006b. Effect of a dietary essential oil mixture on performance of laying hens in the summer season. S. Afr. J. anim. Sci., 36: 215.

Craig, W.J., 1999. Health-promoting properties of common herbs. Am. J. chin. Nutri, 70 (suppl.), 491499.

Cross, D. E., R. M. McDevitt, K. Hillman and T. Acamovic, 2007. The effect of herbs and their associated essential oils on performance, dietary digestibility and gut microflora in chickens from 7 to 28 days of age. . Br. Poult. Sci. 48: 496-506.

Coles, E. H., 1974. Veterinary clinical pathology. PP. 211-213, W.B. Saunders, Company, Philadalphia, London, Toronto.

Demir, E., S. Sarica, M. A. Özcan and M. Suiçmez, 2005. The use of natural feed additives as alternative to an antibiotic growth promoter in broiler diets. Archive fur Geflugelkunde, 69: 110-116.

Denli, M., F. Okan, and A. N. Uluocak. 2004. Effect of dietary supplementation of herb essential oil on the growth performance, carcass and intestinal characteristics of quail (Coturnix coturnix japonica). S. Afr. J. Anim. Sci. 34:174-179.

Duncan, D. B., 1955. Multiple ranges and multiple F test. Biometrics, 11:1-42.

Eltazi, S. A., 2014. Effect of using dietary antibiotic and anise oil as feed additives on performance and carcass quality of broiler chicks. Assiut Vet. Med. J. Vol. 60 No.142.

Ertas, O. N., T. Guler, M. Ciftci, B. Dalkilic and G. Simsek, 2005. The effect of essential oil mix derived from oregano, clove and anise on broiler performance. Int. J. Poult. Sci. 4 (11): 879-884.

Giannenas, I., P. P. Florou, M. Papazahariadou, E. Christaki, N. A. Botsoglou and A. B. Spais, 2003. Effect of dietary supplementation with oregano essential oil on performance of broilers after experimental infection with Eimeria tenella. Archive Tierernhrung, (57): 99-106.

Gulcin, I., M. Oktay, E. Kirecci and O. K. Irfan, 20003. Screening of antioxidant and antimicrobial activities of anise (Pimpinella anisum L.) seed extract. Food Chem., 83: 371-382. 
Heady, E. O. and H. R. Jensen, 1954. Farm Management Economics. Prentice-Hall Inc. Englewood Cliffs, N. J., USA.

Hernandez, F., J. Madrid, V. Garcia, J. Orengo and M. D. Megias, 2004. Influence of two plants extract on broiler performance digestibility and digestive organ size. Poult. Sci., 83: 169-174.

Jamroz, D., J. Orda, C. Kamel, A. Wiliczkiewicz, T. Wertelecki and J. Skorupinska, 2003. The influence of phytogenetic extracts on performance, nutrient digestibility, carcass characteristics and gut microbial status in broiler chickens. J. Anim. Feed Sci. 12: 583-96.

Jamroz, D., A. Wiliczkiewicz, T. Werteleck1, J. Orda and J. Sukorupinska, 2005. Use of active substances of plant origin in chicken diets based on maize and locally grown cereals. Br. Poult. Sci. 46, 485-493.

Janahmadi, M., S. Farajnia, J. Vatanparast, H. Abbasipour and M. Kamalinejad, 2008. The fruit essential oil of Pimpinella anisum L. (umbelliferae) induces neuronal hyperexcitability in snail partly through attenuation of after-hyperpolarization. J. Ethnopharmacol., 120: 360-365.

Jang, I. S., Y. H. Ko, H. Y. Yang, J. S. Ha, J. Y. Kim, S. Y. Kang, D. H. Yoo, D. S. Nam,D. H. Kim, and C. Y. Lee, 2004. Influence of essential oil components on growth performance and the functional activity of the pancreases and small intestine in broiler chickens. Asian Aust. J. anim. Sci., 17: 394400.

Kirsti T., H. Kettunen, M. H. L. Bento, M. Saarinen, S. Lahtinen, A.C. Ouwehand, H. Schulze and N. Rautonen 2010. The effect of feeding essential oils on broiler performance and gut microbiota. Br. Poult. Sci. 51: 381-392.

Langhout P., 2000. New additives for broiler chickens. World Poult. Elsevier, 16, 22-26. 26.

Lee, K.W., H. Everest, H. J. Kappert, K. H. Yeom and A. C. Beynen, 2003. Dietary carvacrol lowers body weight gain but improves feed conversion in female broiler chickens. Appli. Poult. Res., 12: 394-399.

Lemhadri, A., 2004: Anti - hyperglycemic activity of the aqueous extract of Origanum vulgre (Oregano) growing voild in Tafilalet region. J. Ethnopharmacol. 92: 251-256.

Madpouly, H. M., M. A. Saif, A. S. Hussein, 2011. Curcuma longa for protecting chicks against Newcastle disease virus infection and immunosuppressive effect of Marek's disease viral vaccine. In. J. of Virology, 7: 176-83.

National Research Council (NRC), 1994.Nutrient requirements of Poultry. $9^{\text {th }}$ Rev.ed Ed., National Academy Press, Washington, DC.

Ocak N., G. Erener, F. Burak, M. Sungu, A. Altop and A. Ozmen, 2008. Performance of broilers fed diets supplemented with dry peppermint (Mentha piperita L.) or thyme (Thymus vulgaris L.) leaves as growth promoter source. Czech J. Anim. Sci. 53(4): 169-75.

Osman, N. E., G. Talat, C. Mehmet, D. Bestami and U. G. Simsek, 2005. The effect of an essential oil mix derived from oregano, clove and anise on broiler performance. Int. J. Poult. Sci., 4: 879-884.

Oyen L. P. A. and N. X. Dung, 1999. Plant resources of South East Asia No. 19. Essential-oil plants. Backhuys Publishers.

Ozek K., K. T. Wellmann, B. Ertekin and B. Tarım, 2011. Effects of dietary herbal essential oil mixture and organic acid preparation on laying traits, gastrointestinal tract characteristics, blood parameters and immune response of laying hens in a hot summer season. Journal of Animal and Feed Sciences, 20 (9): 575-586.

Pourgholam, M. H., S. Majzoob, M. Javadi, M. Kamalinejad, G. H. Fanaee and M. Sayyah, 1999. The fruit essential oil of Pimpinella anisum exerts anticonvulsant effect in mice. J. Ethnopharmacol., 66: 211-215.

Rezaei, M. A., D. Mohajeri, B. Rafiei, R. Dizaji, A. Azhdari, M. Yeganehzad, M. Shahidi and M. Mazani, 2012. Effect of turmeric and carrot seed extracts on serum liver biomarkers and hepatic lipid peroxidation, antioxidant enzymes and total antioxidant status in rats. BioImpacts, 2: 151-57.

Simsek, U. G., M. Ciftci, B. Dalkilic, T. Guler and O. N. Ertas, O.N. 20007. The effect of dietary antibiotic and anise oil supplementation on body weight, carcass characteristics and organoleptic analysis of meat in broiler. Revue. Med. Vet. 158(10): 514-518. 


\section{Hussein}

Soliman, K. M. and R. I. Badea, 2002. Effect of oil extracted from some medicinal plants on different mycotoxigenic fungi. Food Chem. Toxicol., 40: 1669-1675.

Soltan, M. A., R. S. Shewita and M. I. El-Katcha, 2008. Effect of dietary anise seeds supplementation on growth performance, immune response, carcass traits and some blood parameters of broiler chickens. Int. J. Poult. Sci., 7: 1078-1088.

SPSS. 2011. SPSS 11.0 for Windows. SPSS Inc., Chicago. Standardization administration of china. 2005. National feed Industry Standards for Enzyme Assays in China.

Tabanca, N., E. Bedir, N. Kirimer, K. H. Baser, S. I. Khan, M. R. Jacob and I. A. Khan, 2003. Antimicrobial compounds from Pimpinella species growing in Turkey. Planta Medical, 69: 933-938.

Viuda, M. M., Y. Ruiz-Navajas, J. Fernández-López and J. A. Pérez-Alvarez, 2010. Spices as functional foods. Critical Reviews in Food Science and Nutrition, 51: 13-28.

Williams P. and R. Losa, 2001. The use of essential oils and their compounds in poultry nutrition. World Poultry-Elsevier, 17, 14-15.

Zanaty, G. A. and Sh. A. M. Ibrahim, 2005. Optimum dietary protein and energy levels of Norfa chicks during the periods of zero to eight and eight to sixteen weeks of age. Egypt Poult. Sci. Vol (25) (III): $(589-612)$.

Zhang, K. Y. F. Yan, C. A. Keen and P. W. Waldroup, 2005. Evaluation of microencapsulated essential oils and organic acids in diets for broiler chickens. Int. J. Poult. Sci. 4(9):612- 619.

\section{تأثير اضافة زيت الينسون فى علائق كتاكيت النورفا على الأداء الإتتاجى وبعض صفات الام}

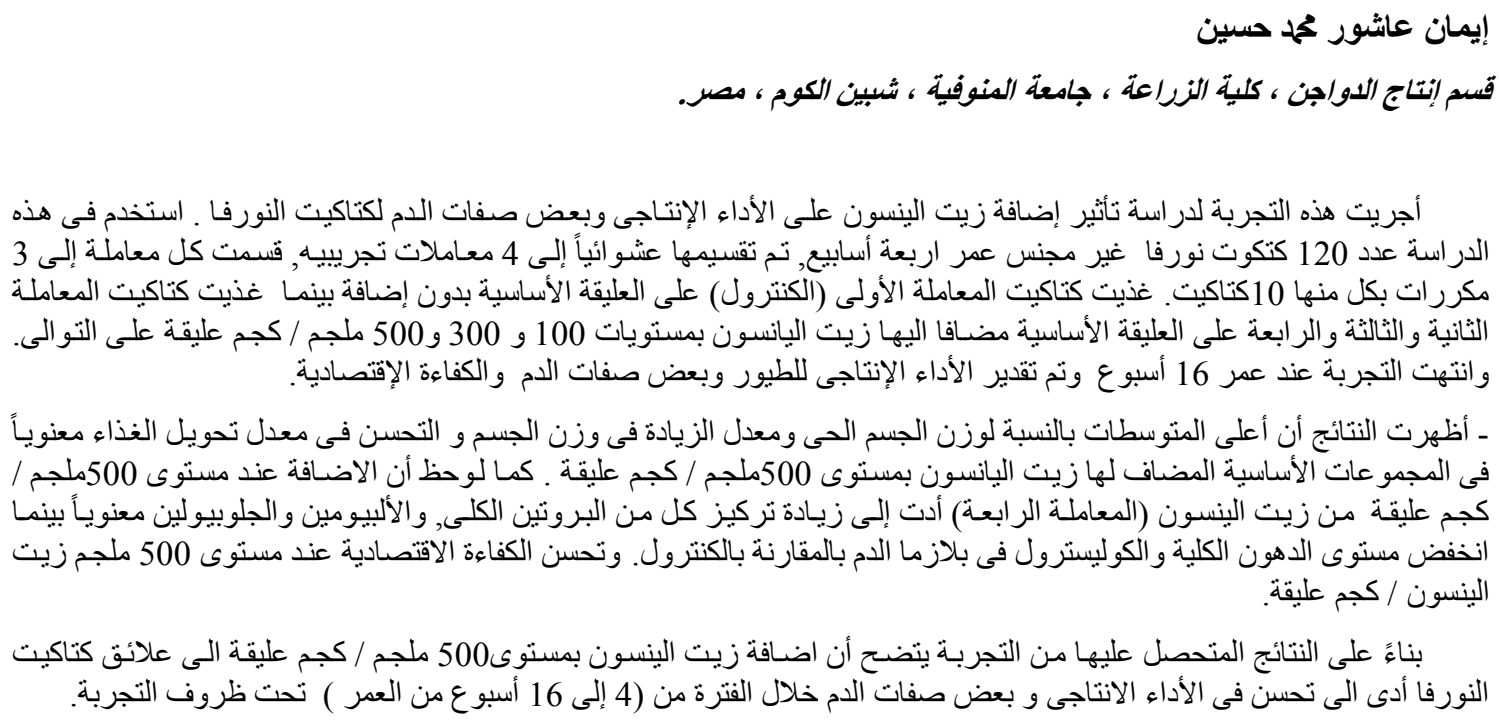

